\title{
Organization of Transcribed and Nontranscribed Chromatin
}

\author{
W.W. Franke ${ }^{1}$, U. ScheER ${ }^{1}$, H. ZentGRaF ${ }^{2}$ \\ M.F. TrendelenburG ${ }^{1}$, U. MÜller ${ }^{3}$, G. KrOHne $^{1}$ \\ and $\mathrm{H}$. SPRING ${ }^{1}$ \\ Abteilung für Membranbiologie und Biochemie \\ Institut für experimentelle Pathologie, Deutsches Krebsforschungszentrum \\ ${ }^{2}$ Institut für Virologie, Deutsches Krebsforschungszentrum \\ ${ }^{3}$ Institut für Mikrobiologie der Universität \\ 6900 Heidelberg, FRG
}

\section{Introduction}

In most eukaryotic nuclei two extreme forms of chromatin packing can be distinguished, condensed and dispersed chromatin. This does not exclude that, in addition, transitional or intermediate forms may exist. Ever since the pioneering morphological studies of Heitz $(1929,1932,1956)$ cytologists have associated condensed chromatin, including the "heterochromatin" sensu Heitz (cf. also Brown 1966), with transcriptional inactivity, as opposed to the various levels of transcriptional activity thought to exist in regions of dispersed ("extended") chromatin, including the puffs and Balbiani rings described in polytene chromosomes of various dipteran insects (Pelling 1964; for refs. see Beermann 1972) and the loops of lampbrush chromosomes (Gall and Callan 1962). The discovery of the nucleosome ( $v$-body) as a subunit of chromatin organization (Olins and Olins 1973, 1974; Woodcock 1973; Kornberg 1974; for recent reviews see Chambon 1978; Felsenfeld 1978), which is the predominant structure of first order packing in transcriptionally inactive chromatin, has led to the question whether the packing of DNA is different in transcriptionally active chromatin. In the context of the present study we define the nucleosome as a particle of about $10-13 \mathrm{~nm}$ overall diameter which contains a defined octamer of histones and a total of about 200 base pairs of DNA (for details see Kornberg 1974, 1977; Oudet et al. 1975; Felsenfeld 1978). Inherent in this definition is a formula of packing of DNA, resulting in a linear foreshortening, relative to the DNA molecule in B-conformation, of about 5.3 (for electron microscopic demonstrations of this packing of DNA in isolated nucleosomes see, e.g., also Woodcock et al. 1976). In order to avoid a misunderstanding frequent in the literature we want to emphasize that we do not use the term "nucleosome", in the context of this article, for any unit of 140-200 base pairs of DNA packed with proteins in a way that protects it from digestion with certain endonucleases such as micrococcal nuclease (see also below). We designate "nucleosome" only the particulate unit ("soma", i.e., body) as defined above. 


\section{Biochemical Evidence for Structural Differences in Transcriptionally Active Chromatin}

Studies with deoxyribonuclease I have shown that transcribed chromatin of nucleolar as well as non-nucleolar origin is more sensitive to digestion than nontranscribed chromatin (Weintraub and Groudine 1976; see also Garel and Axel 1976, 1978; Flint and Weintraub 1977; Bellard et al. 1978; Levy et al. 1978; Mathis and Gorovsky 1978; Palmiter et al. 1978; Paul et al. 1978; Suzuki and Ohshima 1978). Differential kinetics of digestion of DNA present in transcriptionally active chromatin has also been demonstrated with deoxyribonuclease II (Gottesfeld and Butler 1977) and with micrococcal nuclease, both in non-nucleolar (e.g., Bellard et al. 1978; Bloom and Anderson 1978) and nucleolar (Reeves and Jones 1976; Reeves 1978; cf. Allfrey et al. 1978) genes. Transcriptionally engaged subunits of nucleolar chromatin obtained by nuclease digestion in Physarum polycephalum have been reported to have sedimentation properties and protein composition different from those obtained from typical nucleosomes (e.g., Allfrey et al. 1978). A series of compositional differences, including histone modifications, have been reported in isolated transcriptionally active chromatin from various sources (Levy-Wilson et al. 1977; Allfrey et al. 1978; Bonner et al. 1978; Gottesfeld 1978; for further refs. see Chambon 1978). Structural differences between "active" and "inactive" chromatin fractions have also been described by Moudrianakis et al. (1977) who concluded from their experiments that "nontranscribable chromatin is in the form of a string of contiguous, about $100 \AA$-diameter beads, whereas transcribable chromatin is in the form of relatively smooth fiber ca. $35 \AA$ thick" (see also remark by E.N. Moudrianakis in the discussion of the paper by V.E. Foe 1978).

Digestion experiments with micrococcal nuclease have shown that the DNA of transcriptionally active chromatin is arranged in a protection pattern similar to that described in inactive chromatin (for refs. see Bonner et al. 1978; Garel and Axel 1978; Gottesfeld and Melton 1978; Mathis and Gorovsky 1978). However, the demonstration of a periodical arrangement of protective entities, most probably histones, does not allow the discrimination between the extended and the compacted state of the nucleosome-equivalent nucleo-histone unit (e.g., Jackson and Chalkley 1975; Oudet et al. 1978a,b; Woodcock and Frado 1978; cf. also Yaneva and Dessev 1976).

\section{Nucleosomal Structure of Inactive Chromatin as Revealed by Electron Microscopy}

When transcriptionally inactive chromatin, which in most cell types constitutes the bulk of the nuclear chromatin, is dispersed in buffer solutions of low ionic strength and examined in the electron microscope, for example by the use of the "spreading technique" developed by Miller and co-workers (Miller and Beatty 1969; Miller and Bakken 1972), the typical "beads-on-string" arrays are observed (Fig. 1; cf. Figs. 4d, 7c, 8a and e; cf. Olins and Olins 1973, 1974; Woodcock 1973). In 
such preparations, however, the individual nucleosomal particles are not always closely spaced, as it is probably the case in situ, but can show various degrees of greater nucleosome spacing. In different preparations, or in different strands of the same preparation, or even in different regions of the same chromatin strand, beads are arranged in close spacing, often arranged in a typical zig-zag pattern, or may show more or less extended internucleosomal "linker" regions (Fig. 1; see refs. quoted above). Consequently, in such preparations the apparent DNA packing ratio does not seem to be constant but varies from about 5 as in close spacing (see above; such a value is also caused by preparations made from solutions of nearly physiological ionic strength; cf. Griffith 1975; cf. Griffith and Christiansen 1978; Keller et al. 1978; Zentgraf et al. 1978) to an average of about 2 which is usually found after prolonged incubation in media of very low salt concentrations (e.g., below $1 \mathrm{mM}$ alkali salt; Fig. 1; cf. Foe et al. 1976; Foe 1978; McKnight et al. 1978; Reeder et al. 1978a). Similar mean contraction ratios of 2.0 to 2.5 has also been oberserved in spread preparations of chromatin containing well defined circular DNA molecules such as SV40 DNA (Fig. 8a; for refs. see Griffith 1975; Griffith and Christiansen 1978; Keller et al. 1978; Müller et al. 1978; Oudet et al. 1978a,b; Zentgraf et al. 1978), nontranscribed amplified rDNA of oocytes of Dytiscus marginalis (Fig.4; for details see Scheer and Zentgraf 1978), as well as nontranscribed SV 40 DNA (Laskey et al. 1978), plasmid DNA (Trendelenburg and Gurdon 1978), and mitochondrial DNA (Fig. 8e; H. Zentgraf, M.F. Trendelenburg, and W.W. Franke, unpublished results) that have been injected into nuclei of oocytes of Xenopus laevis (for possible mechanisms of nucleosome packing of microinjected DNA see Laskey et al. 1978). The reason for the observed variations of nucleosome packing in chromatin that has been dispersed and spread in low salt buffers is not clear. Experiments suggest that the specific packing density of nucleosomal particles depends on the ionic strength and the $\mathrm{pH}$ of the solutions used, the time of incubation, the mode of preparation, and the type of chromatin examined (see also below).

\section{Ultrastructure of Transcriptionally Active Chromatin}

In view of the predominance, in most nuclei, of inactive or only weakly active chromatin we want to begin this discussion, for the sake of clarity, with a description of the one extreme, i.e., fully transcribed chromatin as is found, for example, in nucleoli containing actively transcribed genes coding for pre-rRNA (Fig. 2) or in lampbrush chromosome loops (Fig. 3). In electron micrographs of spread preparations such highly active chromatin is characterized by the predominance of transcriptional complexes which appear as lateral ribonucleoprotein (RNP) fibrils containing the forming RNA growing from the RNA-polymerase particles attached to the chromatin axis (cf. Miller and Beatty 1969; Franke et al. 1976a, 1978a,b; Franke and Scheer 1978). The following situations can be distinguished: 


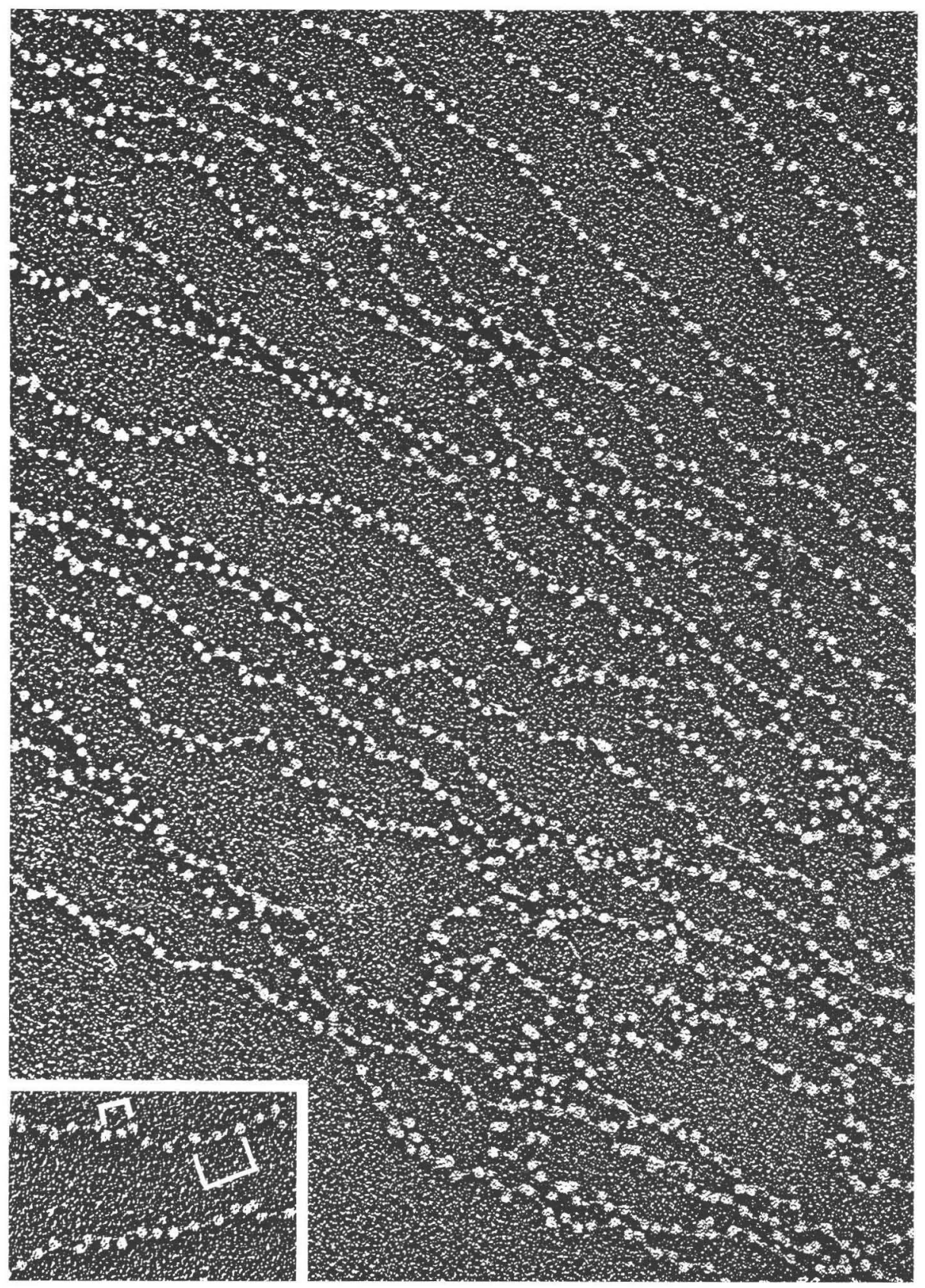

Fig. 1. Survey electron micrograph showing the appearance of hen erythrocyte chromatin when dispersed in low salt buffer, spread and metal shadowed (for methodical details see Franke et al. 1976a). Note the characteristic nucleosomal "beads-on-a-string" organization of the chromatin strands. Some variation of center-to-center distances of nucleosomes can be observed, sometimes even on the same chromatin strand. The insert shows one example (bracket in the left) of long spacing, with a mean distance of about $38 \mathrm{~nm}$ (corresponding to a 

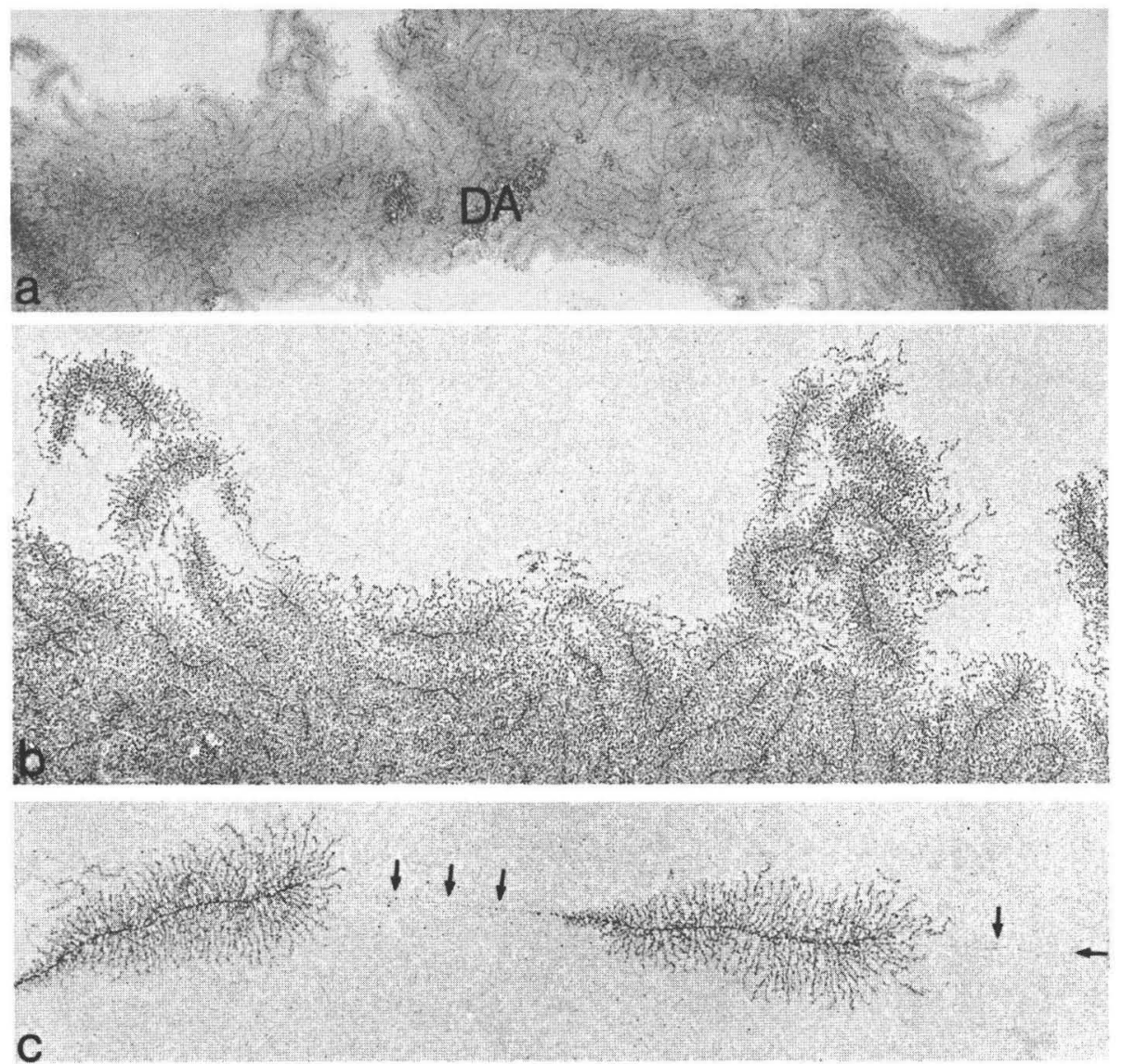

Fig. 2a-c. Nucleolar chromatin of the primary nucleus of the green algae Acetabularia mediterranea (Fig. 2a and b) and Acetabularia cliftonii (Fig. 2c). a shows a large mass of aggregated, fully active pre-rRNA genes, reflecting the aggregated state of this material in situ $(D A$, dense aggregate structure, which is often seen in central portions of such nucleolar spread preparations. $\mathbf{b}$ is a higher magnification of the previous figure, showing the individual transcriptional units in the margin of the spread nucleolar mass. c shows a typical example of a well-spread strand of transcriptionally active nucleolar chromatin, characterized by tandemly arranged pre-rRNA genes and interspersed spacer regions (arrows). Note that the axis of the spacer is relatively thin and does not show nucleosomesized particles. The mean length of the transcriptional units (e.g., ca. $2.2 \mu \mathrm{m}$ in the strand shown in c), recognized by the associated lateral RNP-fibrils containing the nascent prerRNA, is in fair correspondence to the size of the pre-rRNA isolated from such nuclei (Spring et al. 1974, 1976). a: $\times 4,300 ; \mathbf{b : ~} \times 11,600 ; \mathbf{c}: \times 15,500$

DNA packing ratio of about 1.7); the smaller bracket indicates an example of relatively close spacing, here with a mean distance of $22 \mathrm{~nm}$ (corresponding to a foreshortening ratio, relative to B-conformation DNA, of about 2.9). These estimations are based on a value of 200 base pairs of DNA per nucleosome and nucleosome-equivalent unit, respectively, and the electron microscopic DNA reference values given by Stüber and Bujard (1977). The heterogeneity in the spacing of nucleosome particles may have been artificially induced during the preparation. $\times 78,000$; insert, $\times 80,000$ 


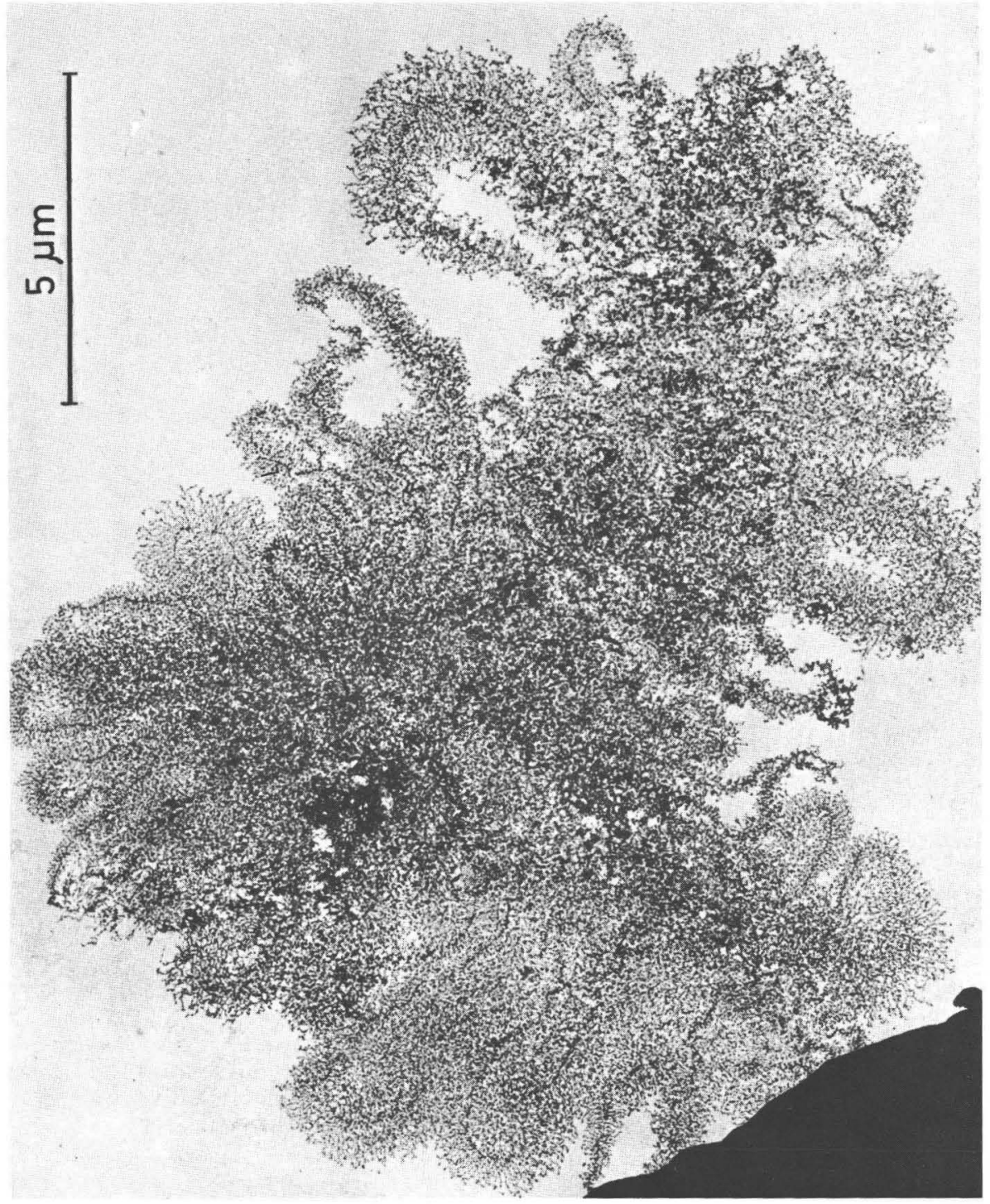

Fig. 3. Actively transcribed non-nucleolar chromatin as seen in a spread and positively stained whole lampbrush chromosome from a primary nucleus of the green alga Acetabularia mediterranea (for preparation see Spring et al. 1975). Note the numerous loops of various lengths, each containing transcriptional units. $\times 12,500$ 


\section{A. Nucleolar Chromatin}

1. Fully active transcriptional units are recognized as "matrix units" showing close spacing of transcriptional complexes (Figs. 2, 4c, 5). In such matrix units one does not reveal additional nucleosome-sized particles that are free of lateral RNP fibrils; nor does one regularly see extended nonbeaded regions of chromatin axis as this would have to be expected if nucleosomes would exist in such regions but would unfold during the preparation. In many, though not in all (cf. Trendelenburg et al. 1973, 1976) organisms, the length and the DNA content of the matrix units corresponds to the sizes of the specific pre-rRNA's isolated from the same cells which are assumed to represent the primary - or at least only slightly processedproducts of transcription (Scheer et al. 1973; Spring et al. 1974, 1976; Foe et al. 1976; Franke et al. 1976a, 1978a,b; Laird et al. 1976; Scheer et al. 1977; Foe 1978; McKnight et al. 1978; Reeder et al. 1978b; see these for further references).
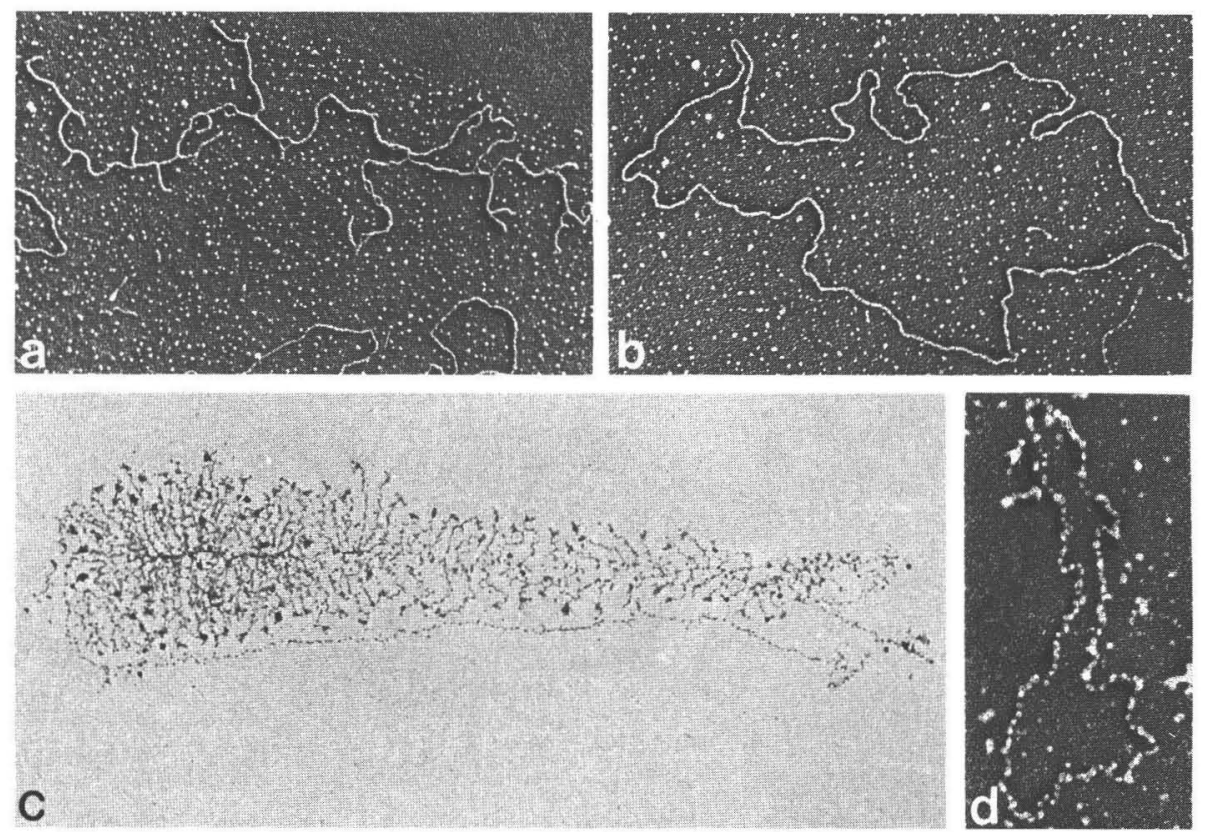

Fig. 4a-d. Electron microscopy of purified amplified rDNA and of nucleolar chromatin from the water beetle Dytiscus marginalis. Isolated circular rDNA appears in spread preparations either as supercoiled (a) or relaxed molecules (b); the contour length of this one pre-rRNA gene containing molecule is $8.6 \mu \mathrm{m}$. In spread preparations of transcriptionally active nucleolar chromatin the rings of the smallest size class, i.e., those containing one transcriptional unit and a spacer unit, reveal the typical arrangement of fibril-covered matrix units and fibril-free, thin spacer intercepts (c); contour length of the circle shown here is ca. $8.7 \mu \mathrm{m}$. By contrast, when rings of the smallest size class are isolated from transcriptionally inactive, rDNAcontaining chromatin, e.g., from previtellogenic oocytes, they show the beaded nucleosomal organization and the expected foreshortening that results from rDNA packing into nucleosomes (d); contour length of the chromatin circle shown here is $3.35 \mu \mathrm{m}$ (for details see Scheer and Zentgraf 1978). This illustrates that rDNA is extended in transcriptionally active stages and is packed into nucleosomes when inactive. a-c: $\times 24,000 ; \mathbf{d}: \times 42,000$ 


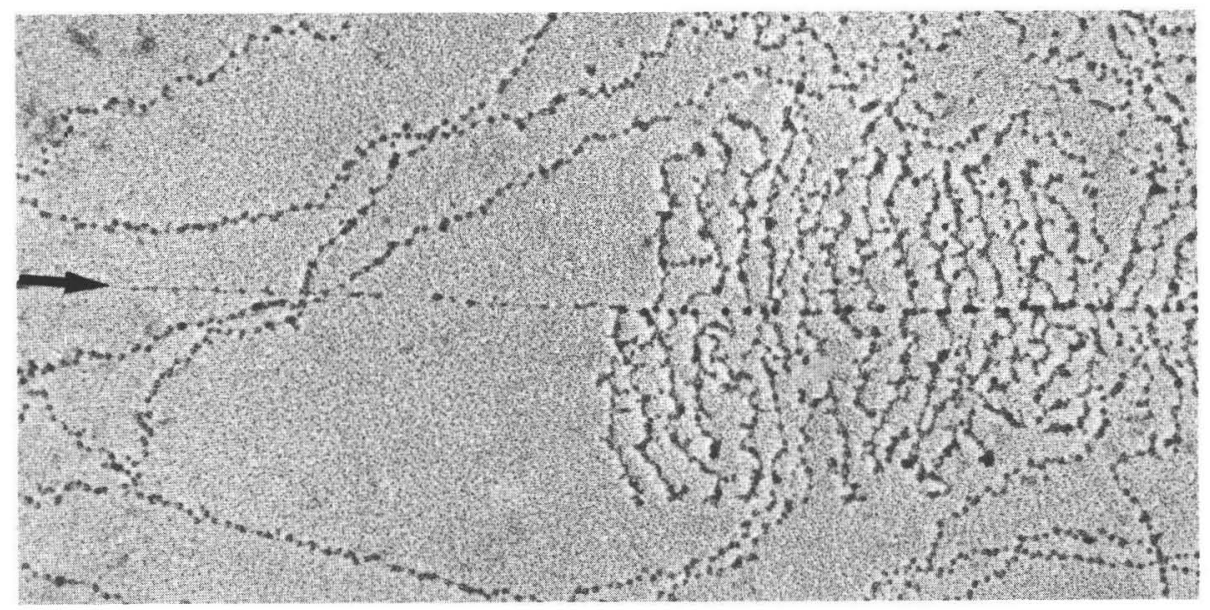

Fig. 5. Nucleolar chromatin of reduced transcriptional activity (preparation from a nearly mature oocyte of the Alpine newt, Triturus alpestris) often shows a "mixed appearance in spread preparations (cf. Scheer et al. 1976a; Franke et al. 1978a,b; Scheer 1978). Inactive chromatin fibrils show the typical nucleosomal ("beaded") organization and can be observed next to transcriptionally active rDNA regions characterized by fibril-covered matrix units and adjacent thin, nearly smooth ("nonbeaded") spacer intercepts. $\times 42,000$

2. Apparent spacer regions (for definitions see Franke et al. 1976a,b, 1978a,b) interspersed between matrix units show only few, frequently none, nucleosomesized particles (e.g., Foe et al. 1976; Franke et al. 1976a,b, 1978a,b; Foe 1978; Villard and Fakan 1978). Although it has been suggested by some authors that these particles represent nucleosomes (Foe et al. 1976; Woodcock et al. 1976; Foe 1978) several observations tend to indicate that such particles are not of nucleosomal nature (for definition see above) and that spacer regions located between fully active matrix units are not packed into nucleosomes, at least not in a mode similar to that observed in inactive chromatin from the same nucleus or even the same nucleolus:

a) Some spacer-associated particles of $10-13 \mathrm{~nm}$ diameter are preserved after treatment with Sarkosyl NL-30 at concentrations which result in the removal of histones (Franke et al. 1976a, 1978a,b; Scheer et al. 1977).

b) Some spacer-associated particles are associated with short lateral fibrils similar to those seen in matrix units (Scheer et al. 1973, 1977; Franke et al. 1976b). This, together with the observation mentioned under (a), suggests that at least some of the spacer-associated particles represent RNA-polymerase molecules and transcriptional complexes, respectively (for the special situation for 5fluorouridine-treated nucleoli see also Rungger et al. 1978).

c) The DNA present in spacer regions is not considerably contracted (estimated contraction ratios ranging from 1.0 to 1.24 have been reported; Franke et al. 1976a, 1978a,b; Trendelenburg et al. 1976, 1978; Scheer et al. 1977; Franke and Scheer 1978; Reeder et al. 1978a; McKnight et al. 1978; for a comparison of mammalian rDNA repeating units and spacer units see also Puvion-Dutilleul and May 1978). 
d) An especially clear demonstration of the altered configuration in spacer chromatin is the finding (see Melton et al., this vol.) that plasmids containing both spacer and pre-rRNA gene regions which are transcribed upon injection into germinal vesicles of Xenopus laevis show nucleosome-sized particles only in the nontranscribed plasmid DNA region but not in the extended transcribed gene region and the adjacent rDNA spacer region.

From this, we conclude, in harmony with other authors (Reeder et al. 1978a), that the DNA of spacer regions is also only slightly, if at all, contracted and thus cannot be packed in nucleosomes. We cannot decide, however, whether the obvious structural difference of rDNA spacer chromatin in active nucleoli reflects the true absence of nucleosomes in situ or a greater selective susceptibility of these nucleosomes, if they exist, to unfolding forces exerted during the preparation. Moreover, we want to mention various other alternatives for explaining the occasional observations of beadlike particles of nucleosomal size in spacer regions: these particles could represent histone complexes such as nucleosome-derived octamers, reaggregated histones, other protein aggregates, regular stain deposits, et cetera.

3. Regions in pre-rRNA matrix units of reduced transcriptional activity, which are recognized by reduced packing densities of transcriptional complexes (i.e., "gaps" within matrix units; cf. Scheer et al. 1975, 1976a), have also been shown to display a "smooth", i.e., nonnucleosomal appearance (Franke et al. 1976a, 1978a,b; Foe 1978; Scheer 1978). This observed absence of nucleosomal particles in partly inactive pre-rRNA genes is consistent with the finding that the lengths of such matrix units of reduced lateral fibril densities are not considerably decreased, i.e., the rDNA apparently remains in an extended, non-nucleosomal form (Franke et al. 1976a; Scheer et al. 1976a; cf. Foe 1978).

4. Regions of nucleolar chromatin that correspond to pre-rRNA genes but are not associated with identifiable transcriptional complexes sometimes also show a smooth, i.e., non-nucleosomal appearance and seem to contain extended DNA (Franke et al. 1976a, 1978a,b; Scheer et al. 1976a, 1977; Foe 1978). Such situations have been described during embryogenesis of the milkweed bug, Oncopeltus fasciatus (Foe et al. 1976; Foe 1978) during oogenesis of various amphibians ${ }^{1}$ (Franke et al. 1976a; Scheer et al. 1976a; Scheer 1978) and during drug-induced inhibition of nucleolar transcription (cf. Scheer et al. 1975; Franke et al. 1976a).

1 While lampbrush chromosome loop retraction as well as centripetal accumulation and condensation of nucleoli are striking during late oogenesis in several urodelan species (for refs. see Scheer et al. 1976a), concomitant with progressively reduced transcriptional activity, such phenomena are much less pronounced in the oogenesis of the anuran species, Xenopus laevis. Late stages of oogenesis of Xenopus laevis, often collectively classified as stage 6 (cf. Scheer 1973), show much less reduced transcriptional activity (Anderson and Smith 1977, 1978). It should be kept in mind, however, that these oocytes are heterogeneous within one ovary as well as among different females (cf. also Anderson and Smith 1977). Moreover, the comparison of, e.g., maximal activity in stage 3 and 4 in fully active oocytes of hormonetreated frogs with the activity of stage 6 oocytes has indicated a reduction by $40-50 \%$ in the later stage (Anderson and Smith 1978). It is to be emphasized, however, that some nucleoli of late stages of Xenopus oogenesis do clearly show absence of matrix units in some regions, as opposed to residual transcriptional activity in other regions of the same strand (cf. Scheer 1978). 
This phenomenon has been interpreted to reflect the conversion of chromatin from the nucleosomal to the extended state, prior to transcription (Foe 1978), and vice versa, shortly after cessation of transcription (Franke et al. 1976a; Scheer et al. 1976a; Scheer 1978).

5. Transcriptionally inactive nucleolar chromatin can be identified in early stages of embryogenesis of some insects (Foe et al. 1976; McKnight and Miller 1976; Foe 1978), in early, i.e., previtellogenic, and very late, i.e., during or after the lampbrush chromosome loop retraction phase, stages of amphibian or insect oogenesis (Scheer et al. 1976a; Scheer 1978; Scheer and Zentgraf 1978) and after drug-induced inhibition of transcription (Scheer et al. 1975; Franke et al. 1978a,b). Here chromatin regions that contain pre-rRNA genes seem to be packed in nucleosomes indistinguishable from those present in other kinds of inactive chromatin (Franke et al. 1976a, 1978a,b; Foe 1978; Scheer 1978; Scheer and Zentgraf 1978). This demonstrates that inactive nucleolar chromatin assumes the nucleosomal form, resulting in a contraction of the rDNA similar to that described in various other kinds of DNA.

\section{B. Non-Nucleolar Chromatin}

1. The organization of intensely transcribed, non-nucleolar genes has been studied in lampbrush chromosome loops (Fig. 3; for refs. see Scheer et al. 1976b, 1978) and in the putatively identified transcriptional unit of the silk fibroin gene of Bombyx mori (cf. McKnight et al. 1978). Both situations are characterized by dense packing of transcriptional complexes, absence of additional nucleosome-sized particles, and an apparently extended DNA (Franke et al. 1976a, 1978a,b; Scheer et al. 1976b, 1978; Franke and Scheer 1978; McKnight et al. 1978).

2. Transcriptional units of non-nucleolar genes that show a markedly reduced transcriptional activity, as seen from the relatively large distances between transcriptional complexes ("gaps"), often but not always (Franke et al. 1976a) reveal nucleosome-like particles located in the chromatin axis intercepts between the transcriptional complexes (cf. Foe et al. 1976; Laird et al. 1976; McKnight and Miller 1976; Foe 1978; Franke et al. 1978b; McKnight et al. 1978; Scheer 1978). The nucleosomal nature of these beads located between transcriptional complexes has also been demonstrated by their disappearance during de-histonization using Sarkosyl (Scheer 1978). This situation seems to be also present in transcriptionally active SV40 chromatin in which only few transcriptional complexes seem to be present per molecule (for discussion see Keller et al. 1978; Müller et al. 1978).

From these observations we conclude that fully active non-nucleolar chromatin is also present in a non-nucleosomal form, i.e., with its DNA extended. However, in moderately or weakly active chromatin, which in most nuclei seems to represent the bulk of the total transcribed chromatin, chromatin intercepts that are located between two transcriptional complexes assume, probably as a transient state, the nucleosomal form (for detailed discussion see Franke et al. 1978a,b; Scheer 1978). In other words, transcriptionally inactive regions within transcribed genes often seem to assume the same organization as that present in other inactive chromatin. This suggests that unfolding and reformation of nucleosomes can take place in relatively short periods of time. The rates of such conformational changes of 

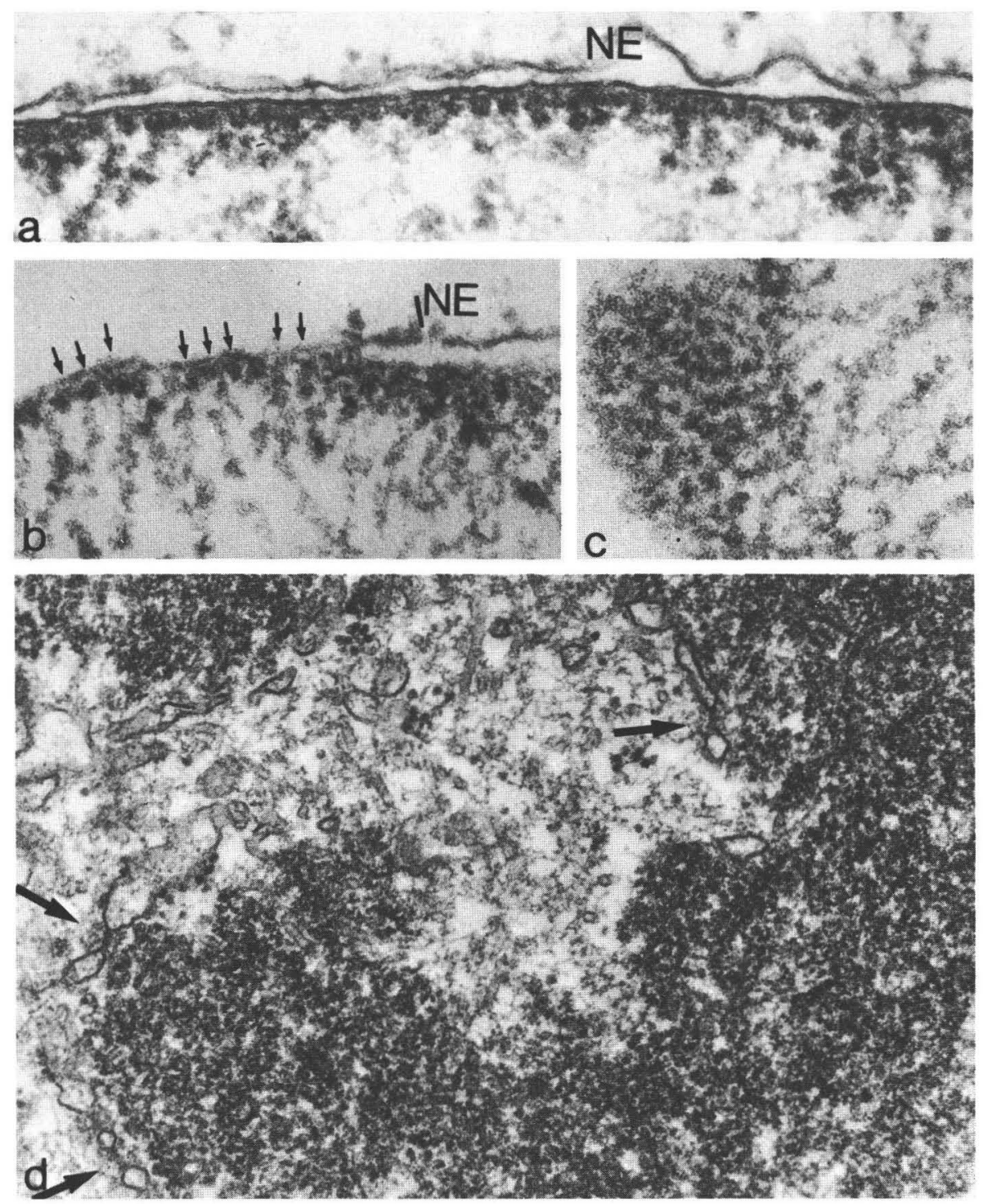

Fig. 6a-d. Electron micrographs of ultrathin sections showing large ("supranucleosomal") granules of chromatin to be especially prominent in the peripheral condensed chromatin (a-c) and in mitotic chromosomes (d). a shows large chromatin granules in the most peripheral layer of chromatin associated with the inner membrane of the nuclear envelope (NE) of a cultured murine 3T3 cell (cf. Franke et al. 1978a) b and $\mathbf{c}$ show, in cross section (b) and in grazing section (c), the relatively high resistance of the large chromatin granules (some are denoted by arrows in b) attached to the inner nuclear membrane to treatment with low salt media that promote dispersion and swelling of the chromatin (examples are in isolated calf thymocytes; cf. Franke and Scheer 1974). The late anaphase chromosomes of cultured thymic epithelial cells of the rat (d), attached with small pieces of reforming nuclear envelope (arrows denote pore complexes; note also ribosomes associated with both sides of some of these pore complex-containing units, indicative of their origin from endoplasmic reticulum), show most of their chromatin arranged in $18-32 \mathrm{~nm}$ large granules. a: $\times 60,000 ; \mathbf{b}, \mathbf{c}: \times 100,000$ d: $\times 63,000$ 

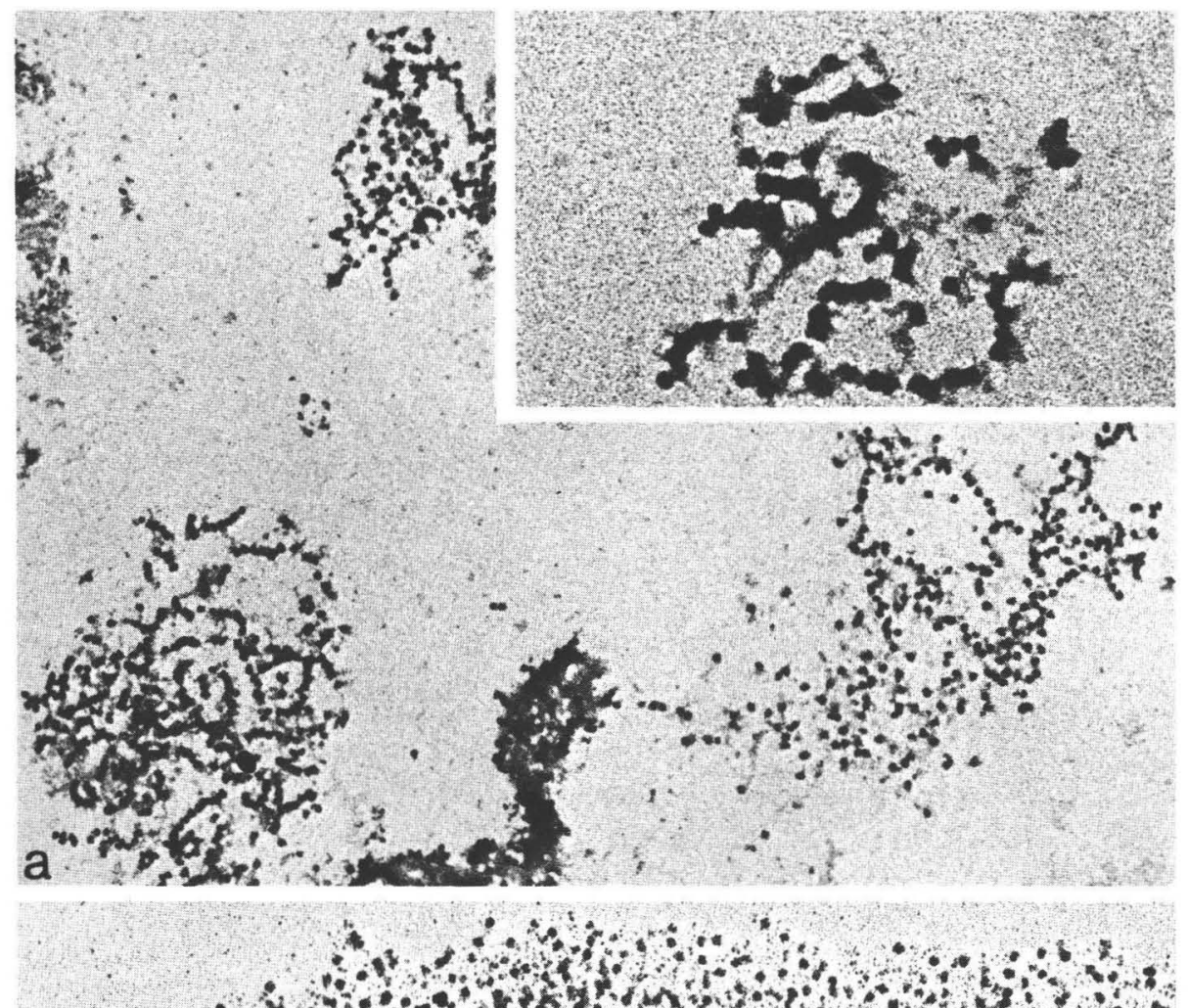

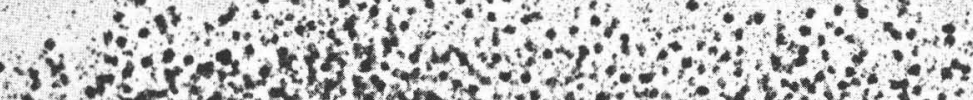

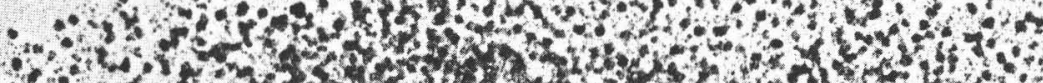
- ar.

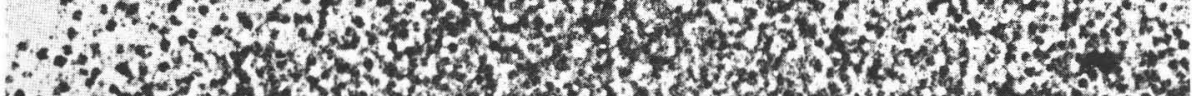

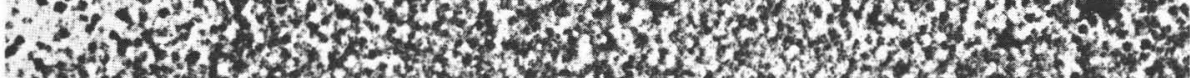

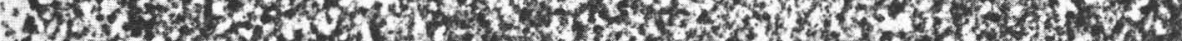

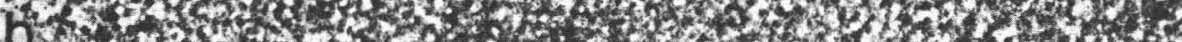

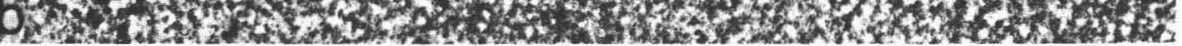

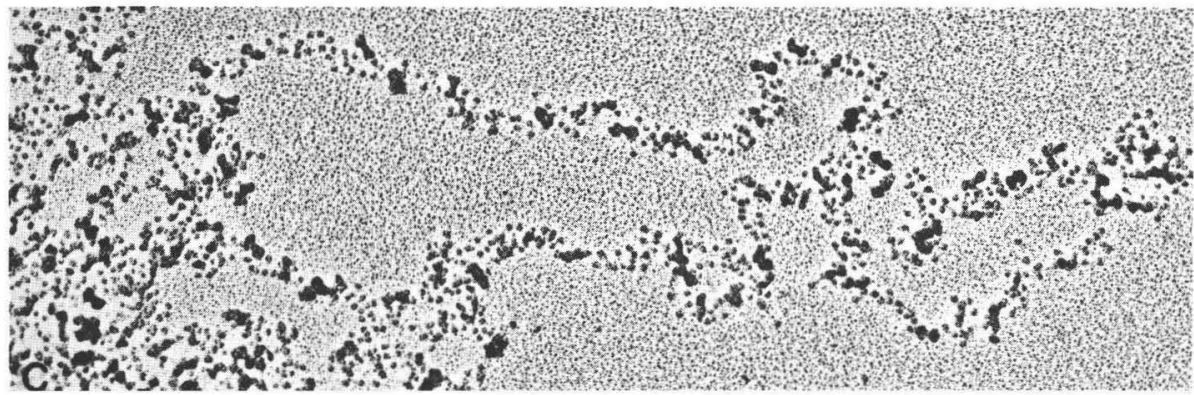

Fig. 7a-c. Occurrence of large (18-32 nm) chromatin granules representing supranucleosomal orders of chromatin packing as revealed after dispersion of chromatin in low salt buffers and spreading preparation according to Miller and Beatty $(1969$; for specific modification see Franke et al. 1976a). a shows typical arrays of "superbeads" seen in a cultured cell (monkey kidney CV 1; for similar observations made in other cultured cells and for details of preparation see Franke et al. 1976a, 1977). The insert in a shows the chain-like arrays of 
chromatin organization during transcription may vary in different situations and different genes. A certain retention phase of the conformational changes accompanying a transcriptional event is also suggested by some biochemical results indicating that the selectively higher DNAse I sensitivity characteristic of transcribed chromatin remains for some time after cessation of transcription (e.g., Weintraub and Groudine 1976; Palmiter et al. 1978; see also Chambon 1978).

The concept of a non-nucleosomal organization of transcribed chromatin does not imply the absence of histones in such regions. Evidence available, though still rather scarce, suggests that histones are present in transcriptionally active chromatin (e.g., McKnight et al. 1978), including nucleolar chromatin (Higashinakagawa et al. 1977; Reeder et al. 1978b) and lampbrush chromosome loops (U. Scheer and R. Sperling, unpublished observations by immunofluorescence microscopy) of amphibian oocytes. The presence of histones in transcribed chromatin regions is also suggested from the results obtained by digestion of DNA containing genes assumed to be transcribed using micrococcal nuclease (for refs. see above and Franke et al. 1978a,b; Mathis and Gorovsky 1978; Reeves 1978). The specific molecular architecture of the histone arrangement in transcribed chromatin will have to be elucidated in future experiments.

\section{Supranucleosomal Organization Observed in Transcriptionally Inactive Chromatin}

Chromatin, which is transcriptionally inactive for extended periods of time or is constitutively nontranscribable (see also definition of constitutive heterochromatin, the refs. given in Introduction), frequently shows an especially prominent condensed appearance. Such chromatin appears to be not only completely compacted in nucleosomes but also presents a distinct form of higher order packing of the "nucleofilament" (for terminology see Klug 1978; Worcel 1978). Certain highly condensed chromatin structures such as pericentromeric and telomeric heterochromatin, the nuclear envelope-attached condensed chromatin, chromatin predominant in spermatids and spermatozoa of various species, chromatin of pyknotic nuclei and maturing nucleated erythrocytes show, in ultrathin sections, arrays of chain-like large closely juxtaposed chromatin granules (diameters 18-32 nm; cf. Fig. 6; see Franke and Scheer 1974, 1978; Zentgraf et al. 1975; Philipp et al. 1976; Franke et al. 1978a,b; see these refs. for further literature).

supranucleosomal granules at higher magnification. $\mathbf{b}$ and $\mathbf{c}$ show the appearance of chromatin of sea urchin sperm (Psammechinus miliaris) in either predominantly large granular (b) or more solenoid-like (c) arrangements. The chromatin shown in Fig. b has been prepared by incubation in - and extensive dialysis $\left(12 \mathrm{~h}, 4{ }^{\circ} \mathrm{C}\right)$ against - buffer without chelateforming components ( $200 \mathrm{mM} \mathrm{KCl}, 10 \mathrm{mM}$ pipes, $\left.2 \mathrm{mM} \mathrm{CaCl}_{2}, \mathrm{pH} 6.8\right)$, followed by direct transfer onto a "cushion" of $0.1 \mathrm{M}$ sucrose in low salt borate buffer $(\mathrm{pH} 8.5)$ containing $1 \%$ formaldehyde and centrifugation (cf. Franke et al. 1976a); the preparation has been positively stained and shadow cast (see Franke et al. 1976a). In the preparation shown in c sperm has been incubated for $15 \mathrm{~min}$ in slightly alkaline low salt (ca. $0.1 \mathrm{mM}$ ) borate buffer (pH 9) and prepared as described (cf. Miller and Beatty 1969; Franke et al. 1976a). a: $\times 32,000$; insert in a: $\times 76,000 ; \mathbf{b}: \times 23,000 ; \mathbf{c}: \times 48,000$ 

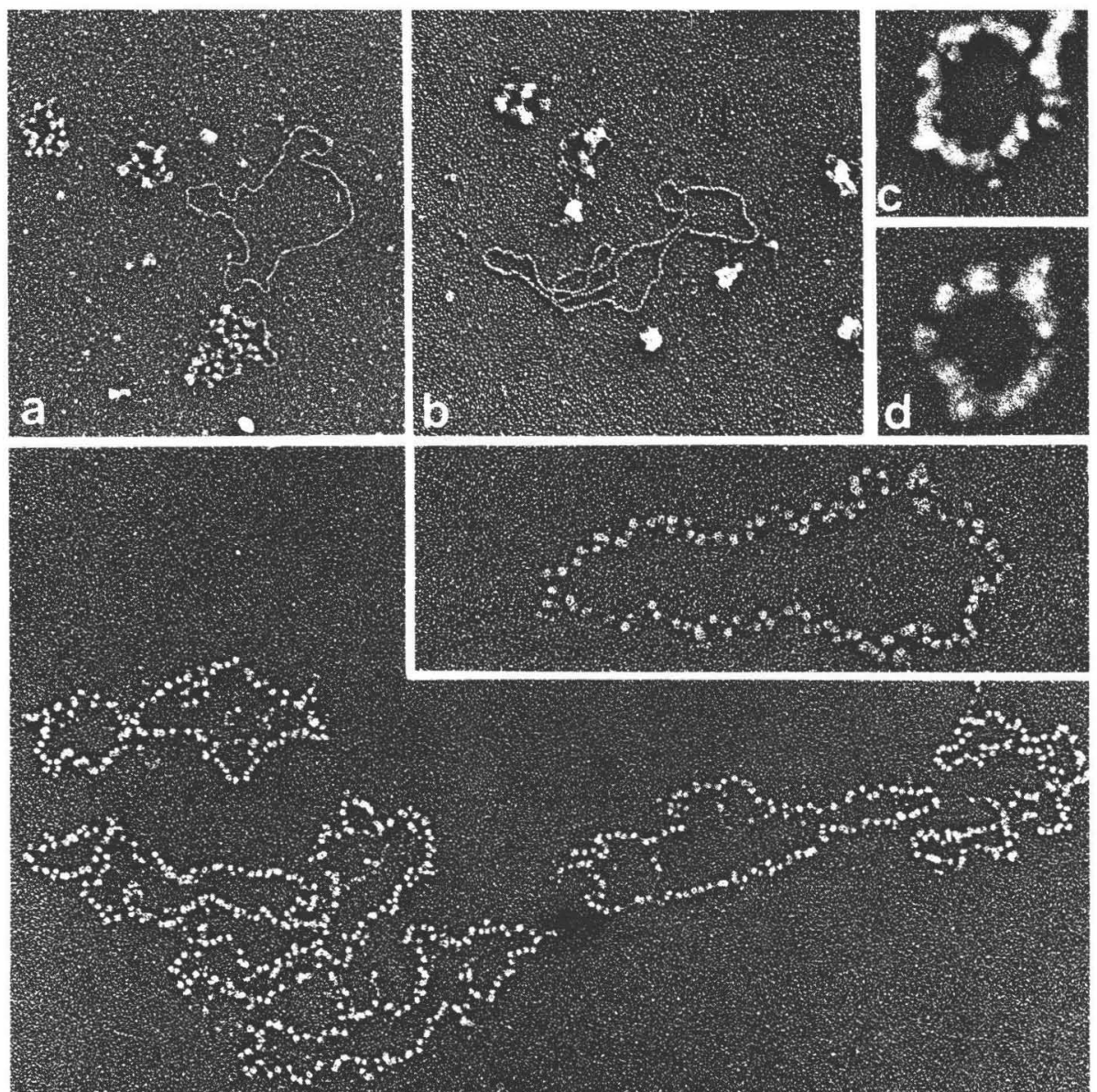

e.

Fig. 8a-e. Nucleosomal and supranucleosomal packing of circular DNA molecules as seen in electron micrographs of spread preparations of chromatin. At the nucleosomal level, the SV40 chromatin prepared from infected cells (for details see Keller et al. 1978; Müller et al. 1978; Zentgraf et al. 1978) shows the typcical beaded appearance and the foreshortening expected for nucleosomal packing (a), whereas the supranucleosomal organization of the SV40 chromatin is identified as a compact large globular structure (b); de-proteinized SV40 DNA has been added in a and $\mathbf{b}$ to demonstrate the packing of the DNA. Supranucleosomal packing is also observed in transcriptionally inactive rDNA circles isolated from nucleolar chromatin of previtellogenic Dytiscus marginalis oocytes (c,d). The globular higher order structures are significantly larger than nucleosomes (compare Fig. 4), and the foreshortening is much greater ( 20 -fold and more) than in the nucleofilament form. e shows the nucleosomal packing of purified mitochondrial DNA from Xenopus laevis oocytes injected into nuclei ("germinal vesicles") of the same cell type. Xenopus laevis oocytes have been injected with 2-4 ng of purified mitochondrial DNA, aimed for the oocyte nuclei, and incubated for 1 day. The oocyte nuclei have then been manually isolated and their contents spread for electron microscopy as described (Trendelenburg et al. 1978). Almost all injected circular molecules are visualized as newly assembled chromatin rings with a typical "beaded" ultrastructure (e); maximally $80-90$ beads per chromatin circle; the insert in e shows a clearly traceable nucleosome-packed circle of mitochondrial DNA at higher magnification. The molecules 
Such large chromatin granules, especially those attached to the nuclear envelope, have also been shown to have a relatively high resistance to swelling and dispersion in solutions of low ionic strength (Fig. 6b,c; cf. Franke and Scheer 1974), compared to the bulk of the chromatin. Apparently it is this property that often allows their demonstration in spread preparations (see above) after relatively short periods of time of incubation in the low salt buffer (Fig. 7; Franke et al. 1976a, 1978a,b; Kiryanov et al. 1976; Olins 1978). During progressive incubation in buffer solutions of low ionic strength one often recognizes transitions from the large granular form to more continuous coil-like fibers, suggestive of a solenoidal arrangement of the nucleosomal chains, and, finally, the extended nucleofilaments (e.g., Fig. 7b,c; cf. Franke et al. 1976a, 1978a,b). Distinct granules ("superbeads", "nucleogranules") 18-32 nm large and containing 6-10 nucleosomes (a maximum of eight has been reported for the granules prepared from rat liver; cf. Strätling et al. 1978a,b) have been isolated by controlled, limited digestion with micrococcal nuclease (Hozier et al. 1977; Renz et al. 1977, 1978; Strätling et al. 1978a,b), and it has been demonstrated that histone $\mathrm{H} 1$ is required for this granular form of regular supranucleosomal packing (same refs.). Related observations of a granular higher order packing of a nucleosomal chain have also been reported from studies on the SV40 chromatin ("minchromosomes") which contains a circular chain of 24-26 nucleosomes that are packed, at nearly physiological ionic strength, in large (about $30 \mathrm{~nm}$ ) aggregates, sometimes allowing the distinction of three or four $17-19 \mathrm{~nm}$ large granular constituents, which in low salt buffers extend into the unfolded, nucleofilament-like state and reversibly fold back to the aggregate state at increasing salt, as long as H1 is present (Fig. 8a,b; cf. Griffith 1975; Griffith and Christiansen 1978; Keller et al. 1978; Müller et al. 1978; Varshavsky et al. 1978; Zentgraf et al. 1978). Higher orders of granular packing of nucleosomes have also been described in another circular DNA molecule, the amplified rDNA of Dytiscus marginalis (Fig. 8c,d; cf. Scheer and Zentgraf 1978). Whether or not the nucleosomal arrays that are newly formed upon exposure of various kinds of DNA to egg cytoplasm or oocyte nuclei of Xenopus laevis (Fig. 8e; cf. Laskey et al. 1978; Trendelenburg and Gurdon 1978; Trendelenburg et al. 1978) are also packed into such granular forms of higher order packing, probably depending on the presence of $\mathrm{H} 1$, remains to be clarified.

\section{Nonhistone Proteins and the Organization of Transcriptionally Active and Inactive Chromatin}

It is obvious that nonhistone proteins play an important role in the morphology of transcriptionally active chromatin since the appearance of these chromatin

shown have mean contour lengths of 2.4-2.5 $\mu \mathrm{m}$, which has to be compared with the length of the purified circular mitochondrial DNA prior to injection $(5.0-5.4 \mu \mathrm{m}$; for refs. see Borst and Kroon 1969; Pinon et al. 1978). This shows that, under the specific preparation and spreading conditions used, the mitochondrial DNA is compacted and foreshortened approx. 2.2 -fold a: $\times 50,000 ; \mathbf{b}: \times 78,000 ; \mathbf{c}, \mathbf{d}: \times 110,000$; $: \times 50,000$; insert in e: $\times 70,000$ 

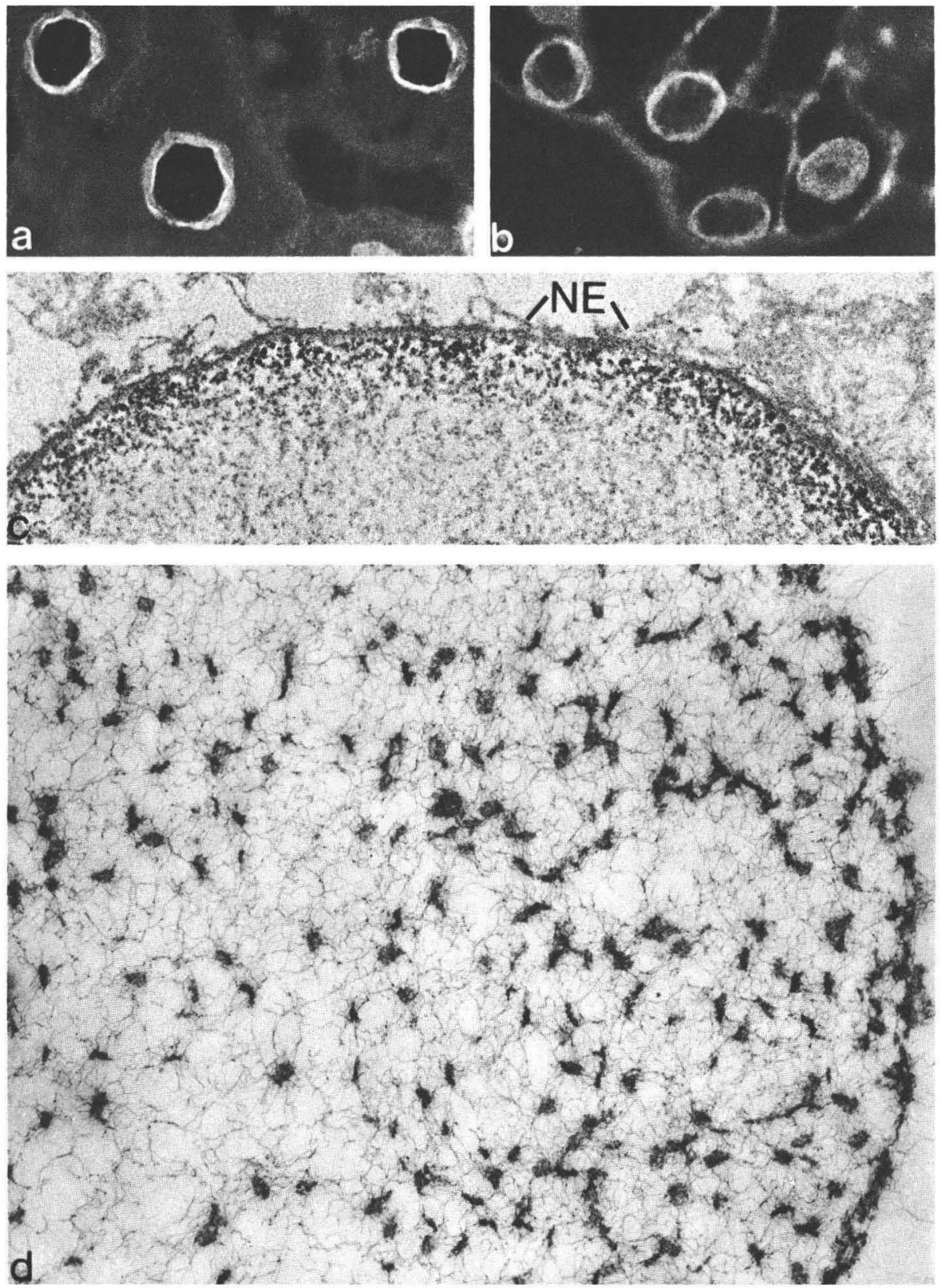

Fig. 9a-d. Demonstration of the involvement of structures containing nonhistone proteins in chromatin organization and topology. a-c present the localization of an "insoluble" major nonhistone protein specifically associated with peripheral chromatin (NE, nuclear envelope) in frozen tissue sections of rat (a, c) and toad (b) Xenopus laevis liver by indirect immunofluorescence microscope $(\mathbf{a}, \mathbf{b})$ and electron microscopy using peroxidase labelling of antibodies (c) for details see Krohne et al. 1978). One of the three major polypeptides of the "nuclear pore complex-lamina" fraction from rat liver, prepared essentially as described by 
regions is characterized and often dominated by the associated RNA polymerases and the proteins associated with the nascent RNA's (see above). However, in view of the appearance of the highly condensed chromatin as aggregates of nucleosomes and supranucleosomal granules, respectively, it is questionable whether the condensed chromatin represents an aggregate of nucleohistone material or whether it contains additional nonhistone proteins. Various authors have described the location of nonhistone proteins in chromatinous and interchromatinous nuclear structures, especially those characterized by a pronounced resistance to treatment with solutions of high and low ionic strength as well as nondenaturing detergents (cf. Georgiev and Chentsov 1960; Berezney and Coffey 1974; Comings and Okada 1976; Dwyer and Blobel 1976; Cobbs and Shelton 1978; Herman et al. 1978; Krohne et al. 1978; Laemmli et al. 1978; Miller et al. 1978; see these for earlier references). In the context of the present discussion we want to present two examples illustrating that some of the "residual" (i.e., those insoluble in low and high salt buffers and nondenaturing detergents) nonhistone proteins are enriched in - and specifically associated with — condensed portions of chromatin. (1) A group of major nonhistone polypeptides appears in residual fractions of whole chromatin of nuclear envelope, and in "matrix" preparations in the form of a characteristic triplet band recognized by gel electrophoresis (approx. mol. wt. ranging from 63,000 to 80,000 ; for refs. see above). Using antibodies raised against the individual polypeptides of this protein fraction, it has been shown that some of them are specifically located, in somatic interphase nuclei, in close association with the peripheral condensed chromatin (Fig. 9a-c; cf. Krohne et al. 1978). The broad range of immunological cross reaction of these proteins in different species (cf. Fig. 9a, b) suggests that they have been strongly conserved during evolution. (2) Another proteinaceous component located in condensed (not histone containing) chromatin of mammalian spermatids and spermatozoa is the "residual" protein (one major polypeptide of ca. $65,000 \mathrm{~mol}$. wt.) that forms a characteristic three-dimensional meshwork with densely aggregated, somewhat regularly distributed "nodules" (Fig. 9d; H. Zentgraf, G. Heil, and W.W. Franke, in preparation; cf. Evenson et al. 1978). The biochemical nature and the functional significance of such major nonhistone proteins that seem to be interspersed as some sort of a fibrillar "cement" between the 18-32 nm large chromatin granules will be subject to future experimental work.

Dwyer and Blobel (1976), was used as antigen (polypeptide "tri-2"; apparent mol. wt. ca. 73,000). Antisera have been produced in chicken (for details see Ely et al. 1978). It cannot be decided whether the decorated protein material is located in large granules of inactive condensed peripheral chromatin or is interspersed between these granules. Essentially similar results have been obtained in frozen sections stained with antibodies against polypeptides "tri-1" and "tri-3". d shows an ultrathin section through the achromatinous residual skeleton of a human spermatozoan nucleus obtained after prolonged treatment $\left(12 \mathrm{~h}, 4{ }^{\circ} \mathrm{C}\right)$ with buffer containing high salt concentrations and a nonionic detergent $(1.5 \mathrm{M}$ $\mathrm{KCl}, 50 \mathrm{mM}$ Tris- $\mathrm{HCl}, \mathrm{pH} 7.2,1 \%$ Triton X-100). After centrifugation at $4,000 \mathrm{~g}$ the resulting pellet has been resuspended ( $3 \mathrm{~h}$ at room temperature) in low salt buffer $(10 \mathrm{mM}$ Tris- $\mathrm{HCl}, \mathrm{pH} 7.2 ; 1 \mathrm{mM}$ EDTA) made $1 \%$ with respect to Sarkosyl NL-97. After washing in low salt buffer without detergent the material has been fixed with buffered $2.5 \%$ glutaraldehyde, postfixed with osmium tetroxide and processed for electron microscopy as described (Franke et al. 1976c). a: $\times 1,000 ; \mathbf{b}: \times 1,200 ; \mathbf{c}: \times 23,000 ; \mathbf{d}: \times 41,500$ 
Acknowledgments. We are indebted to C. Grund and K. Mähler for valuable technical assistance. We are also thankful to Drs. J. Gurdon (MRC Cambridge, England) for help with the DNA injection experiments, W. Keller (University of Heidelberg) for discussion about chromatin organization, and C. Petzelt (German Cancer Research Center) for supply will sea urchins. The work has been supported by the Deutsche Forschungsgemeinschaft.

\section{References}

Allfrey, V.G., Johnson, E.M., Sun, I.Y.-C., Littau, V.C., Matthews, H.R., Bradbury, E.M.: Structural organization and control of the ribosomal genes in Physarum. Cold Spring Harbor Symp. Quant. Biol. 42, 505-514 (1978)

Anderson, D.M., Smith, L.D.: Synthesis of heterogeneous nuclear RNA in fullgrown oocytes of Xenopus laevis (Daudin). Cell 11, 663-671 (1977)

Anderson, D.M., Smith, L.D.: Patterns of synthesis and accumulation of heterogeneous RNA in lampbrush stage oocytes of Xenopus laevis (Daudin). Dev. Biol. 67, 274-285 (1978)

Beermann, W. (ed.): Developmental Studies on Giant Chromosomes. In: Results and Problems in Cell Differentiation, Vol. 4. Berlin-Heidelberg-New York: Springer 1972

Bellard, M., Gannon, F., Chambon, P.: The structure and transcriptional activity of the chromatin containing the ovalbumin and globin genes in chick oviduct nuclei. Cold Spring Harbor Symp. Quant. Biol. 42, 779-791 (1978)

Berezney, R., Coffey, D.S.: Identification of a nuclear protein matrix. Biochem. Biophys. Res. Commun. 60, 1410-1417 (1974)

Bloom, K.S., Anderson, J.N.: Fractionation of hen oviduct chromatin into transcriptionally active and inactive regions after selective micrococcal nuclease digestion. Cell 15, 141-150 (1978)

Bonner, J., Wallace, R.B., Sargent, T.D., Murphy, R.F., Dube, S.K.: The expressed portion of eukaryotic chromatin. Cold Spring Harbor Symp. Quant. Biol. 42, 851-857 (1978)

Borst, P., Kroon, A.M.: Mitochondrial DNA: Physicochemical properties, replication and genetic function. Int. Rev. Cytol. 26, 107-190 (1969)

Brown, S.W.: Heterochromatin. Science 151, 417-425 (1966)

Chambon, P.: Summary: The molecular biology of the eukaryotic genome is coming of age. Cold Spring Harbor Symp. Quant. Biol. 42, 1209-1234 (1978)

Cobbs, C.S., Shelton, K.R.: Major oligomeric structural proteins of the HeLa nucleus. Arch. Biochem. Biophys. 189, 323-335 (1978)

Comings, D.E., Okada, T.A.: Nuclear proteins. The fibrillar nature of the nuclear matrix. Exp. Cell Res. 103, 341-360 (1976)

Dwyer, N., Blobel, G.: A modified procedure for the isolation of a pore complex-lamina fraction from rat liver nuclei. J. Cell Biol. 70, 581-591 (1976)

Ely, S., D'Arcy, A., Jost, E.: Interaction of antibodies against nuclear envelope-associated proteins from rat liver nuclei with rodent and human cells. Exp. Cell Res. 116, 325-331 (1978)

Evenson, D.P., Witkin, S.S., De Harven, E., Bendich, A.: Ultrastructure of partially decondensed human spermatozoan chromatin. J. Ultrastruct. Res. 63, 178-187 (1978)

Felsenfeld, G.: Chromatin. Nature (London) 271, 115-122 (1978)

Flint, S.J., Weintraub, H.M.: An altered subunit configuration associated with the actively transcribed DNA of integrated adenovirus genes. Cell 12, 783-794 (1977)

Foe, V.E.: Modulation of ribosomal RNA synthesis in Oncopeltus fasciatus: An electron microscopic study of the relationship between changes in chromatin structure and transcriptional activity. Cold Spring Harbor Symp. Quant. Biol. 42, 723-740 (1978)

Foe, V.E., Wilkinson, L.E., Laird, C.D.: Comparative organization of active transcription units in Ocopeltus fasciatus. Cell 9, 131-146 (1976)

Franke, W.W., Scheer, U.: Structures and functions of the nuclear envelope. In: The Cell Nucleus (ed. H. Busch), Vol. I, pp. 219-347. New York-London: Academic Press 1974 
Franke, W.W., Scheer, U.: Morphology of transcriptional units at different states of activity. Philos. Trans. R. Soc. London Ser. B 283, 333-342 (1978)

Franke, W.W., Scheer, U., Trendelenburg, M.F., Spring, H., Zentgraf, H.: Absence of nucleosomes in transcriptionally active chromatin. Cytobiology 13, 401-434 (1976a)

Franke, W.W., Scheer, U., Spring, H., Trendelenburg, M.F., Krohne, G.: Morphology of transcriptional units of rDNA. Exp. Cell Res. 100, 233-244 (1976b)

Franke, W.W., Lüder, M.R., Kartenbeck, J., Zerban, H., Keenan, T.W.: Involvement of vesicle coat material in casein secretion and surface regeneration. J. Cell Biol. 69, 173-195 (1976c)

Franke, W.W., Scheer, U., Trendelenburg, M.F., Zentgraf, H., Spring, H.: Morphology of transcriptionally active chromatin. Cold Spring Harbor Symp. Quant. Biol. 42, 755-772 (1978a)

Franke, W.W., Zentgraf, H., Scheer, U.: Supranucleosomal and non-nucleosomal chromatin configurations. 9th Int. Congr. Electron Microsc. Toronto, Vol. III, pp. 573586. Toronto: Microsc. Soc. of Canada 1978b

Gall, J.G., Callan, H.G.: ${ }^{3} \mathrm{H}$-uridine incorporation in lampbrush chromosomes. Proc. Natl. Acad. Sci. USA 48, 562-570 (1962)

Garel, A., Axel, R.: Selective digestion of transcriptionally active ovalbumin genes from oviduct nuclei. Proc. Natl. Acad. Sci. USA 73, 3966-3970 (1976)

Garel, A., Axel, R.: The structure of the transcriptionally active ovalbumin genes in chromatin. Cold Spring Harbor Symp. Quant. Biol. 42, 701-708 (1978)

Georgiev, G.P., Chentsov, Y.S.: On the structure of the cell nucleus. Proc. Acad. Sci. USSR 132, 199-202 (1960)

Gottesfeld, J.M.: Organization of transcribed regions of chromatin. Philos. Trans. R. Soc. London Ser. B 283, 343-357 (1978)

Gottesfeld, J.M., Butler, P.J.G.: Structure of transcriptionally active chromatin subunits. Nucleic Acids Res. 4, 3155-3173 (1977)

Gottesfeld, J.M., Melton, D.A.: The length of nucleosome-associated DNA is the same in both transcribed and nontranscribed regions of chromatin. Nature (London) 273, 317 319 (1978)

Griffith, J.D.: Chromatin structures: Deduced from a minichromosome. Science 187, 1202$1203(1975)$

Griffith, J.D., Christiansen, G.: The multifunctional role of histone H1, probed with the SV40 minichromosome. Cold Spring Harbor Symp. Quant. Biol. 42, 215-226 (1978)

Heitz, E.: Heterochromatin, Chromocentren, Chromomeren. Ber. Dtsch. Bot. Ges. 47, 274284 (1929)

Heitz, E.: Die Herkunft der Chromocentren. Planta 18, 571-637 (1932)

Heitz, E.: Die Chromosomenstruktur im Kern während der Kernteilung und der Entwicklung des Organismus. In: Chromosomes. Lectures held at the Conference on Chromosomes. Wageningen, pp. 5-26. Zwolle: Tjeenk Willink 1956

Herman, R., Weymouth, L., Penman, S.: Heterogeneous nuclear RNA-protein fibers in chromatin depleted nuclei. J. Cell Biol. 78, 663-674 (1978)

Higashinakagawa, T., Wahn, H.L., Reeder, R.H.: Isolation of ribosomal gene chromatin. Dev. Biol. 55, 375-386 (1977)

Hozier, J., Nehls, P., Renz, M.: The chromosome fiber: evidence for an ordered superstructure of nucleosomes. Chromosoma 62, 301-317 (1977)

Jackson, V., Chalkley, R.: The effect of urea on staphylococcal digestion on chromatin. Biochem. Biophys. Res. Commun. 67, 1391-1400 (1975)

Keller, W., Müller, U., Eicken, I., Wendel, I., Zentgraf, H.: Biochemical and ultrastructural analysis of SV40 chromatin. Cold Spring Harbor Symp. Quant. Biol. 42, 227-244 (1978)

Kiryanov, G.I., Manamshjan, T.A., Polyakov, V.V., Fais, D., Chentsov, J.S.: Levels of granular organization of chromatin fibers. FEBS Lett. 67, 323-327 (1976)

Klug, A.: Structure of chromatin. Philos. Trans. R. Soc. London Ser. B 283, 233-239 (1978)

Kornberg, R.D.: Chromatin structure: a repeating unit of histones and DNA. Science 184, 868-871 (1974)

Kornberg, R.D.: Structure of chromatin. Annu. Rev. Biochem. 46, 931-954 (1977) 
Krohne, G., Franke, W.W., Ely, S., D’Arcy, A., Jost, E.: Localization of a nuclear envelopeassociated protein by indirect immunofluorescence microscopy using antibodies against a major polypeptide from rat liver fractions enriched in nuclear envelope-associated material. Cytobiol. 18, 22-38 (1978)

Laemmli, U.K., Cheng, S.M., Adolph, K.W., Paulson, J.R., Brown, J.A., Baumbach, W.R.: Metaphase chromosome structure: The role of nonhistone proteins. Cold Spring Harbor Symp. Quant. Biol. 42, 351-360 (1978)

Laird, C.D., Wilkinson, L.E., Foe, V.E., Chooi, W.Y.: Analysis of chromatin-associated fiber arrays. Chromosoma 58, 169-190 (1976)

Laskey, R.A., Honda, B.M., Mills, A.D., Morris, N.R., Wyllie, A.H., Mertz, J.E., De Robertis, E.M., Gurdon, J.B.: Chromatin assembly and transcription in eggs and oocytes of Xenopus laevis. Cold Spring Harbor Symp. Quant. Biol. 42, 171-178 (1978)

Levy, B.W., Wong, N.C.W., Watson, D.C., Peters, E.H., Dixon, G.H.: Structure and function of the low-salt extractable chromosomal proteins. Preferential association of trout testis proteins $\mathrm{H} 6$ and HMG-T with chromatin regions selectively sensitive to nucleases. Cold Spring Harbor Symp. Quant. Biol. 42, 793-801 (1978)

Levy-Wilson, B., Gjerset, R.A., McCarthy, B.J.: Acetylation and phosphorylation of Drosophila histones. Distribution of acetate and phosphate groups in fractionated chromatin. Biochim. Biophys. Acta 475, 168-175 (1977)

Mathis, D.J., Gorovsky, M.A.: Structure of rDNA-containing chromatin of Tetrahymena pyriformis analyzed by nuclease digestion. Cold Spring Harbor Symp. Quant. Biol. 42, 773-778 (1978)

McKnight, S.L., Miller, O.L.: Ultrastructural patterns of RNA synthesis during early embryogenesis of Drosophila melanogaster. Cell 8, 305-319 (1976)

McKnight, S.L., Sullivan, N.L., Miller, O.L.: Visualization of the silk fibroin transcription unit and nascent silk fibroin molecules on polyribosomes of Bombyx mori. Progr. Nucleic Acids Res. 19, 313-318 (1976)

McKnight, S.L., Bustin, M., Miller, O.L.: Electron microscopic analysis of chromosome metabolism in the Drosophila melanogaster embryo. Cold Spring Harbor Symp. Quant. Biol. 42, 741-754 (1978)

Miller, O.L., Bakken, A.H.: Morphological studies of transcription. Acta Endocrinol. Suppl. 168, 155-177 (1972)

Miller, O.L., Beatty, B.R.: Visualization of nucleolar genes. Science 164, 955-957 (1969)

Miller, T.E., Huang, C.Y., Pogo, A.O.: Rat liver nuclear skeleton and ribonucleo-protein complexes containing HnRNA. J. Cell Biol. 76, 675-691 (1978)

Moudrianakis, E.N., Anderson, P.L., Eickbush, H.T., Longfellow, D.E., Pantazis, P., Rubin, R.L. In: The Molecular Biology of the Mammalian Genetic Apparatus (ed. P. T'so), p. 301. Amsterdam: Elsevier/North Holland 1977

Müller, U., Zentgraf, H., Eicken, I., Keller, W.: Higher order structures of SV40 chromatin. Science 201, 406-419 (1978)

Olins, A.: v-Bodies are close-packed in chromatin fibers. Cold Spring Harbor Symp. Quant. Biol. 42, 325-329 (1978)

Olins, A.L., Olins, D.E.: Spheroid chromatin units ( $v$-bodies). J. Cell Biol. 59, 252a (1973)

Olins, A.L., Olins, D.E.: Spheroid chromatin units (v-bodies). Science 183, 330-332 (1974)

Oudet, P., Gross-Bellard, M., Chambon, P.: Electron microscopic and biochemical evidence that chromatin structure is a repeating unit. Cell 4, 281-300 (1975)

Oudet, P., Germond, J.E., Bellard, M., Spadafora, C., Chambon, P.: Nucleosome structure. Philos. Trans. R. Soc. London Ser. B 283, 241-258 (1978a)

Oudet, P., Spadafora, C., Chambon, P.: Structure of the SV40 minichromosome and electron microscopic evidence for reversible transitions of the nucleosome structure. Cold Spring Harbor Symp. Quant. Biol. 42, 301-312 (1978b)

Palmiter, R.D., Mulvihill, E.R., McKnight, G.S., Senear, A.W.: Regulation of gene expression in the chick oviduct by steroid hormones. Cold Spring Harbor Symp. Quant. Biol. 42, 639-647 (1978)

Paul, J., Zollner, E.J., Gilmour, R.S., Birnie, G.D.: Properties of transcriptionally active chromatin. Cold Spring Harbor Symp. Quant. Biol. 42, 597-603 (1978) 
Pelling, C.: Ribonukleinsäure-Synthese der Riesenchromosomen. Autoradiographische Untersuchungen an Chironomus tentans. Chromosoma 15, 71-122 (1964)

Philipp, E., Franke, W.W., Keenan, T.W., Stadler, J., Jarasch, E.: Characterization of nuclear membranes and endoplasmic reticulum isolated from plant tissue. J. Cell Biol. 68, 11-29 (1976)

Pinon, H., Buvat, M., Tourte, M., Dufresne, C., Mounolou, J.C.: Evidence for a mitochondrial chromosome in Xenopus laevis oocytes. Chromosoma 65, 383-389 (1978)

Puvion-Dutilleul, F., May, E.: Visualization of mouse DNA transcriptional complexes in mouse kidney cells infected with SV40 virus. Cytobiol. 18, 294-308 (1978)

Reeder, R.H., McKnight, S.L., Miller, O.: Contraction ratio of the nontranscribed spacer of Xenopus rDNA chromatin. Cold Spring Harbor Symp. Quant. Biol. 42, 1174-1177 (1978a)

Reeder, R.H., Wahn, H.L., Botchan, P., Hipskind, R., Sollner-Webb, B.: Ribosomal genes and their proteins from Xenopus. Cold Spring Harbor Symp. Quant. Biol. 42, 1167-1177 (1978b)

Reeves. R.: Structure of Xenopus ribosomal gene chromatin during changes in genomic transcription rates. Cold Spring Harbor Symp. Quant. Biol. 42, 709-722 (1978)

Reeves, R., Jones, A.: Genomic transcriptional activity and the structure of chromatin. Nature (London) 260, 495-500 (1976)

Renz, M., Nehls, P., Hozier, J.: Involvement of histone H1 in the organization of the chromosome fiber. Proc. Natl. Acad. Sci. USA 74, 1879-1883 (1977)

Renz, M., Nehls, F., Hozier, J.: Histone H1 involvement in the structure of the chromosome fiber. Cold Spring Harbor Symp. Quant. Biol. 42, 245-252 (1978)

Rungger, D., Crippa, M., Trendelenburg, M.F., Scheer, U., Franke, W.W.: Visualization of rDNA spacer transcription in Xenopus oocytes treated with fluorouridine. Exp. Cell Res. $116,481-486(1978)$

Scheer, U.: Nuclear pore flow rate of ribosomal RNA and chain growth rate of its precursor during oogenesis of Xenopus laevis. Dev. Biol. 30, 13-28 (1973)

Scheer, U.: Changes of nucleosome frequency in nucleolar and non-nucleolar chromatin as a function of a transcription: an electron microscopic study. Cell 13, 535-549 (1978)

Scheer, U., Zentgraf, H.: Nucleosomal and supranucleosomal organization of transcriptionally inactive rDNA circles in Dytiscus oocytes. Chromosoma 69, 243-254 (1978)

Scheer, U., Trendelenburg, M.F., Franke, W.W.: Transcription of ribosomal RNA cistrons. Exp. Cell Res. 80, 175-190 (1973)

Scheer, U., Trendelenburg, M.F., Franke, W.W.: Effects of actinomycin D on the association of newly formed ribonucleoproteins with the cistrons of ribosomal RNA in Triturus oocytes. J. Cell Biol. 65, 163-179 (1975)

Scheer, U., Trendelenburg, M.F., Franke, W.W.: Regulation of transcription of genes of ribosomal RNA during amphibian oogenesis. J. Cell Biol. 69, 465-489 (1976a)

Scheer, U., Franke, W.W., Trendelenburg, M.F., Spring, H.: Classification of loops of lampbrush chromosomes according to the arrangement of transcriptional complexes. J. Cell Sci. 22, 503-519 (1976b)

Scheer, U., Trendelenburg, M.F., Krohne, G., Franke, W.W.: Lengths and patterns of transcriptional units in the amplified nucleoli of oocytes of Xenopus laevis. Chromosoma 60, 147-167 (1977)

Spring, H., Trendelenburg, M.F., Scheer, U., Franke, W.W., Herth, W.: Structural and biochemical studies of the primary nucleus of two green algal species, Acetabularia mediterranea and Acetabularia major. Cytobiology 10, 1-65 (1974)

Spring, H., Krohne, G., Franke, W.W., Scheer, U., Trendelenburg, M.F.: Homogeneity and heterogeneity of sizes of transcriptional units and spacer regions in nuclear genes of Acetabularia. J. Microsc. Biol. Cell 25, 107-116 (1976)

Spring, H., Scheer, U., Franke, W.W., Trendelenburg, M.F.: Lampbrush-type chromosomes in the primary nucleus of the green alga Acetabularia mediterranea. Chromosoma 50, 25-43 (1975) 
Strätling, W.H., Müller, U., Zentgraf, H.: Supranucleosomal structure of chromatin. Cell Biol. Int. Rep. 2, 495-499 (1978a)

Strätling, W.H., Müller, U., Zentgraf, H.: The higher order repeat structure of chromatin is built up of globular particles containing eight nucleosomes. Exp. Cell Res. 117, 301-311 (1978b)

Stüber, D., Bujard, H.: Electron microscopy of DNA: Determination of absolute molecular weights and linear density. Mol. Gen. Genet. 154, 299-303 (1977)

Suzuki, Y., Ohshima, Y.: Isolation and characterization of the silk fibroin gene with its flanking sequences. Cold Spring Harbor Symp. Quant. Biol. 42, 947-957 (1978)

Trendelenburg, M.F., Gurdon, J.B.: Transcription of cloned Xenopus ribosomal genes visualized after injection into oocyte nuclei. Nature (London) 276, 292-294 (1978)

Trendelenburg, M.F., Scheer, U., Franke, W.W.: Structural organization of the transcription of ribosomal DNA in oocytes of the house cricket. Nature New Biol. 245, 167 (1973)

Trendelenburg, M.F., Scheer, U., Zentgraf, H., Franke, W.W.: Heterogeneity of spacer lengths in circles of amplified ribosomal DNA of two insect species, Dytiscus marginalis and Acheta domesticus. J. Mol. Biol. 108, 453 (1976)

Trendelenburg, M.F., Zentgraf, H., Franke, W.W., Gurdon, J.B.: Transcription patterns of amplified Dytiscus genes coding for ribosomal RNA after injection into Xenopus oocyte nuclei. Proc. Natl. Acad. Sci. USA 75, 3791-3795 (1978)

Varshavsky, A.J., Bakayev, V.V., Nedospasov, S.A., Georgiev, G.P.: On the structure of eukaryotic, prokaryotic, and viral chromatin. Cold Spring Harbor Symp. Quant. Biol. 42, 457-473 (1978)

Villard, D., Fakan, S.: Visualization des complexes de transcription dans la chromatine étalée de cellules de Mammifères. C. R. Acad. Sci. Ser. D 286, 777-780 (1978)

Weintraub, H., Groudine, M.: Chromosomal subunits in active genes have an altered conformation. Science 193, 848 (1976)

Woodcock, C.L.F.: Ultrastructure of inactive chromatin. J. Cell Biol. 59, 368a (1973)

Woodcock, C.L.F., Frado, L.-L.Y.: Ultrastructure of chromatin subunits during unfolding, histone depletion, and reconstruction. Cold Spring Harbor Symp. Quant. Biol. 42, 43-55 (1978)

Woodcock, C.L.F., Sweetman, H.E., Frado, L.L.: Structural repeating units in chromatin II. Their isolation and partial characterization. Exp. Cell Res. 97, 111-119 (1976)

Worcel, A.: Molecular architecture of the chromatin fiber. Cold Spring Harbor Symp. Quant. Biol. 42, 313-324 (1978)

Yaneva, M., Dessev, G.: Persistence of the ten-nucleotide repeat in chromatin unfolded in urea, as revealed by digestion with deoxyribonuclease I. Nucleic Acids Res. 3, 1761-1767 (1976)

Zentgraf, H., Falk, H., Franke, W.W.: Nuclear membranes and plasma membranes from hen erythrocytcs. IV. Characterization of nuclear membrane attached DNA. Cytobiology 11, 10-29 (1975)

Zentgraf, H., Keller, H., Müller, U.: The structure of SV40 chromatin. Philos. Trans. R. Soc. London Ser. B 283, 299-303 (1978) 